\title{
The Determination of Home Accident Risks and Measures to Prevent Accident of Children: Quasi-Experimental Research
}

\section{Çocukların Evlerdeki Kaza Risklerinin Belirlenmesi ve Önlemlerin Alınması: Yarı-Deneysel Araştırma}

\author{
Eda Dolgun ${ }^{1}$, Aslı Kalkım ${ }^{2}$, Sibel Ergün $*^{3}$
}

ÖZET

Giriş: Çalışma 0-6 yaş çocuğu olan ailelerin evlerdeki kaza risklerinin belirlenmesi ve önlemlerin alınması amacıyla planlandı. Yöntem: 0-6 yaş çocuğu olan aileler $(n=21)$ ile gerçekleştirilen yarı deneysel bir çalışmadır. Araştırmanın verileri soru formu ve Ev Güvenlik Kontrol Listesi kullanılarak 1 ay ara ile $2 \mathrm{ev}$ ziyareti yapılarak toplandı. İlk ziyarette riskler belirlendi, aile bilgilendirildi ve ikinci ziyarette verilen bilgiler doğrultusunda alınan önlemler değerlendirildi. Bulgular: Evlere yapılan ilk ziyarette evin en riskli alanlarının mutfak ve oturma odası olduğu bulundu. Birinci ziyarette evlerin mutfak, banyo, oturma odası, yatak odası için belirlenen risklerin verilen eğitimle 2. ziyarette istatistiksel açıdan anlamlı derecede azaldığı saptandı. Sonuç: Ailelere ev kazalarına yönelik verilen eğitimin evlerdeki kaza risklerini azaltmada etkili olduğu görüldü.

Anahtar kelimeler: Kaza, kaza sıklığı, çocuk, sağlık eğitimi

\begin{abstract}
Introduction: This study was planned in order to determine the home accident risks of families with children 0-6 years old. Methods: This semi-experimental study was performed in families with 0-6 years old children $(\mathrm{n}=21)$. Data were collected using a questionnaire and a Home Safety Checklist during two home visits. In the first home visit the risk was determined and families were educated and at the second home visit, which occurred one month later, measures were evaluated based on information provided at the first home visit. Results: After the first home visit, the kitchen and living room were found to be two areas of highest risk. After providing education for the family, the risks identified for the kitchen, bathroom, living room and bedroom in the first visit decreased in a statistically significant manner by the second visit. Conclusion: The provision of home accident education to families was shown to be effective in reducing the risk of home accidents.
\end{abstract}

Keywords: Accidents, accident prevention, children, health education

\footnotetext{
Received / Geliş tarihi: 17.02.2017, Accepted / Kabul tarihi: 14.03.2017

${ }^{1}$ Ege University Nursing Faculty, Department of Surgical Nursing

${ }^{2}$ Ege University Nursing Faculty, Department of Public Health Nursing

${ }^{3}$ Balıkesir University Balıkesir School of Health

*Address for Correspondence / Yazışma Adresi: Sibel Ergün, Balıkesir University Balıkesir School of Health, Balıkesir-TÜRKIYE

E-mail: sibel.ergun@balikesir.edu.tr

Dolgun E, Kalkım A, Ergün S. The Determination of Home Accident Risks and Measures to Prevent Accident of Children: Quasi-Experimental

Research.TJFMPC, 2017;11(2): 100-107.

DOI: $10.21763 /$ tjfmpc.317852
} 


\section{INTRODUCTION}

Accidents, which are an important health problem, occur very frequently in our country and worldwide, leading to death and disability. Home accidents occur more frequently than other types of accidents. This is due to the larger population exposed to accidents in the home environment and the time span in which the possibility of being involved in an accident during a day extends through the entire 24 hours. ${ }^{1}$

The effect of accidents on child health is so great that it cannot be overlooked. Accidents have physical, psychological, and social impacts on children that disturb their health situation and may result in illnesses, disabilities, and even deaths. For this reason, ${ }^{-}$childhood ačcidents are problems that should be dealt with care. ${ }^{2,3}$ Children are at high risk in terms of home accidents due to reasons such as lack of awareness of dangers, susceptibility and vulnerability to environmental risk, and curiosity about finding and learning. ${ }^{4}$ Home accidents involving children pose serious problems for public health in developed and developing countries and the importance of home accidents is increasing. ${ }^{5}$ For this reason, childhood accidents require careful consideration and intervention. . $^{2,3}$

Although the variation among countries and age groups across the world, the proportion of home accidents in all traumas is $25 \%$. There is no accurate figure for home accidents in Turkey, but it is presumed that $18-25 \%$ of all accidents are home accidents. ${ }^{1,6}$ The morbidity and mortality rates relating to traumas are increasing annually in Turkey. Although traffic and work accidents are considered more significant than home accidents in terms of death and disability, home accidents place first in frequency of occurrence among all accidents. ${ }^{1}$

It is the nurse's responsibility to consider the characteristics and environment of the child, to identify risk factors for home accidents, and intervene appropriately. Knowing the risks is critical in order to properly intervene. The group at highest risk comprises children between 0-6 years of age. The major group that should be sensitive to taking the necessary measures to protect children from home accident risks is the child's family and close associates. It is important that families are knowledgeable about accidents that originate in the home and its surroundings. ${ }^{7}$ Home ${ }^{-}$accidents can be prevented through simple home interventions, providing regular training to parents who spend most of their time with children and raising awareness in parents. $^{3}$

This study was conducted to identify accident risks in the homes of families having children 0-6 years of age, and to measure outcomes of an intervention to prevent home accidents.

\section{METHODS}

The study was a quasi-experimental, home-based study, which was conducted between October, 2011 and March, 2012 (six months), with two home visits per family. Since the researchers could not form a control group due to the fact that they could not reach sufficient number of families. Therefore, a quasiexperimental design was chosen. The study was conducted in the homes of families with 0-6-year-old children, who were registered with a Family Healthcare Center in the district of Izmir, Turkey. Inclusion criteria: Families with healthy children aged 0-6, who accepted to participate.

Exclusion criteria: Families, who had children with mental or physical health problems and/or Families, who considered to move during this study.

The study population was included families with 0-6-year-old children, which were registered to a Family Healthcare Center. A purposive sampling was performed. The sample consisted of 350 families and only 21 accepted to participate. A nonprobability sampling method was utilized and families, which met inclusion criteria were selected.

The study data were collected using a questionnaire developed by the researchers, which was prepared according to available literature. ${ }^{8-10}$ The questionnaire included a sociodemographic and a Home Safety Checklist section.

Sociodemographic questionnaire: Included 16 questions related to age, education, and occupation of mothers and fathers, income-expense status of families, family type, number of children, accident history of children, children's age, number of people at home, home type, history of home accident, type of accident, home area where accident occurs, cause of accident.

Home Safety Checklist: Included 40 items on accident risks in the home environment. The checklist consisted of five sections; living room (10 items), kitchen (10 items), bathroom (nine items), balcony (four items), and bedroom (seven items). During home visits, the presence of each item in the home environment were observed. The accident risk score was obtained by assigning 1 point to each item that was associated with any of the risk factors in the home environment and 0 to an item that had no risk factor. To be able to compare the accident risk scores by home area, the mean risk scores were standardized using the formula " $10 \mathrm{x}$ mean/number of items" on the basis of 10 points. Higher accident 
risk scores obtained from the checklist indicated increased home accident risk. The reliability of the checklist was (Kuder-Richardson Formula 20 coefficient $=0.55$ ). This checklist was used for both first and second home visits.

The data were collected through home visits. Face-to-face interviews were conducted with mothers. Observations were made by three researchers. Each family was visited twice at home with an interval of 4 weeks between visits.

Home Visit-I: Firstly, the sociodemographic characteristics of families were determined by the sociodemographic questionnaire. Then the Home Safety Checklist was applied. According to determined risks mothers were given training on accident prevention at home. The mothers were notified that a second home visit will be made four weeks later.

Training on accident prevention at home: Home accident risks defined by Home Safety Checklist were explained to the mothers involved. Appropriate domestic arrangements and ways of eliminating home accident risks were explained. Training sessions lasted 45 to 60 minutes.

Home Visit-II: The accident risks identified in the home environment during the first visit and the possible changes after the training interventions were controlled by the Home Safety Checklist.

Written permission was obtained from the Health Group Directorate of Ödemiş District. Families were informed about the study. Confidentiality was assured and Informed Consent was retrieved from participants.

The data were analyzed using descriptive statistics, Wilcoxon test; Kuder Richardson formula 20 for reliability of home safety checklist Statistical Package for the Social Sciences (SPSS) software (version 17.0) was used. Level of significance was set at 0.05 .

\section{RESULTS}

The mean age of mothers was $29.80 \pm 6.03$ and the mean age of fathers was $35.42 \pm 7.62$. The median number of children in families was 2 (min: 1 , max: 3 ) and $52.4 \%$ of the families had two children. The mean age of the children was $21.55 \pm 22.37$ months (min: 1, max: 71 months). The median number of people living at home was 4 (min: 3 , max: 6) (Table 1). All home environments in the study were apartments. It was observed that more than one quarter of the children had a home accident within the last six months. The majority involved falls.
Nearly two-thirds of the accidents occurred in the living room (Table 2).

Table 1. Sociodemographic characteristics of sample families.

\begin{tabular}{|c|c|c|}
\hline \multicolumn{2}{|l|}{ Sociodemographic } & \multirow[t]{2}{*}{$\%$} \\
\hline Characteristics & $\mathbf{n}$ & \\
\hline \multicolumn{3}{|l|}{ Age of Mother } \\
\hline $21-32$ & 15 & 71.4 \\
\hline $33-45$ & 6 & 28.6 \\
\hline \multicolumn{3}{|l|}{ Education of Mother } \\
\hline $\begin{array}{l}\text { Graduate of primary } \\
\text { school }\end{array}$ & 12 & 57.1 \\
\hline Graduate of secondary school & 3 & 14.3 \\
\hline Graduate of high school & 4 & 19.0 \\
\hline Graduate of university & 2 & 9.5 \\
\hline \multicolumn{3}{|l|}{ Age of Father } \\
\hline $26-37$ & 14 & 66.7 \\
\hline $38-50$ & 7 & 33.3 \\
\hline \multicolumn{3}{|l|}{ Education of Father } \\
\hline Graduate of primary school & 8 & 38.1 \\
\hline Graduate of high school & 8 & 38.1 \\
\hline Graduate of university & 5 & 23.8 \\
\hline \multicolumn{3}{|l|}{ Income status } \\
\hline Income less than expenses & 5 & 23.8 \\
\hline Income equal to expenses & 15 & 71.4 \\
\hline Income more than expenses & 1 & 4.8 \\
\hline \multicolumn{3}{|l|}{ Family type } \\
\hline Nuclear family & 19 & 90.5 \\
\hline Extended family & 1 & 4.8 \\
\hline Fragmented family & 1 & 4.8 \\
\hline \multicolumn{3}{|l|}{ Number of children } \\
\hline 1 & 6 & 28.6 \\
\hline 2 & 11 & 52.4 \\
\hline 3 & 4 & 19.0 \\
\hline \multicolumn{3}{|l|}{ Age of Children* } \\
\hline $0-12$ months & 16 & 55.2 \\
\hline 13-36 months & 6 & 20.7 \\
\hline 37-72 months & 7 & 24.1 \\
\hline \multicolumn{3}{|l|}{ Number of people at home } \\
\hline 3 & 6 & 28.6 \\
\hline 4 & 11 & 52.4 \\
\hline 5 or more & 4 & 19.1 \\
\hline Total & 21 & 100.0 \\
\hline
\end{tabular}

$* n=29$

The mean accident risk score was 9.04+3.57 (min: 2, max: 16) for all areas of the homes (out of total score of 40). According to the standardized mean accident risk scores, the accident risk score was highest in the kitchen $(3.28 \pm 1.61)$ (Table 3).

No relationship was found between the accident risk score for the dangers detected at the first visit and the mother's age and education, 
income status of the family, number of people living at home, or accident history of the child $(\mathrm{p}>0.05)$. A statistically significant correlation was found, when the number of children living at home were compared to the accident risk score $(\mathrm{p}<0.05)$. Risk scores of families, who had a single child were significantly higher than those with three children.

\section{Table 2. Distribution of home accidents experienced by children}

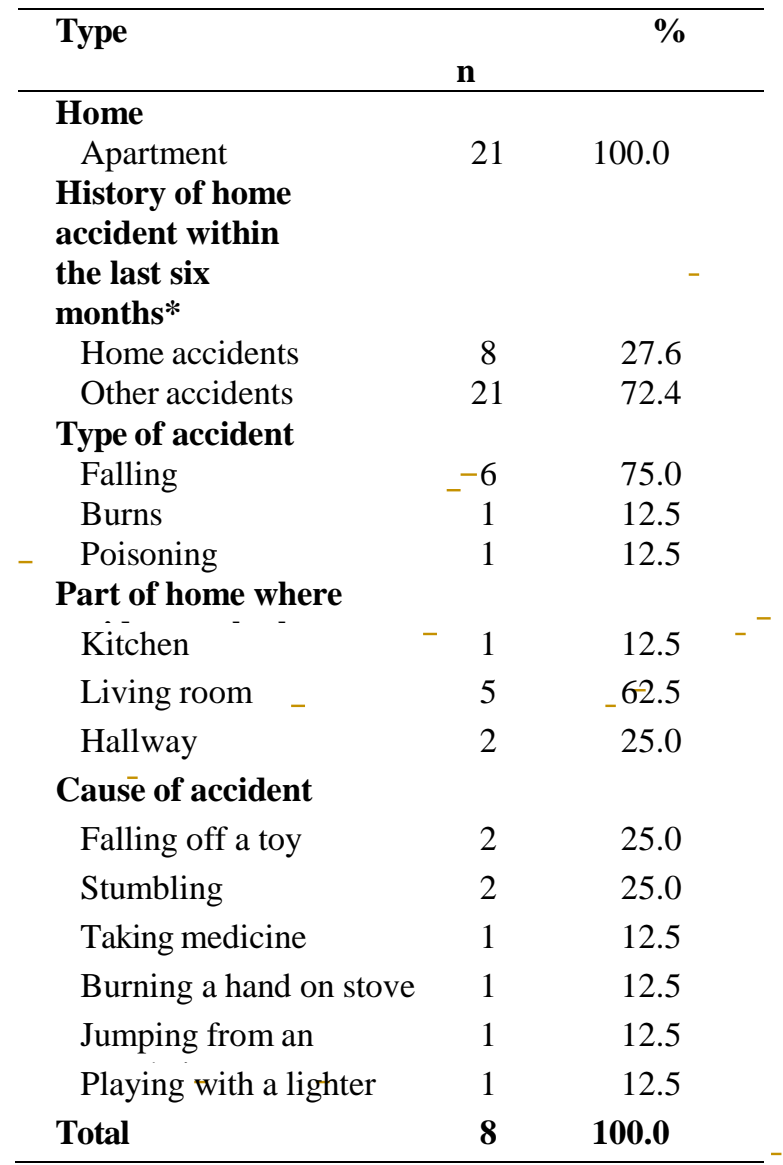

Mean overall accident risk score was 9.04+3.57 (min: 2, max: 16) at Visit I and 3.28 \pm 2.02 (min: 0, max: 8) at Visit II for all home areas. There was a statistically significant difference between the mean overall accident risk scores found at Visit I and II (Z: -3.935, p < 0.001). The mean accident risk score for the kitchen was 3.28 1.61 (min: 1, max: 8) at Visit I and $1.14 \pm 0.96$ (min: 0, max: 4) at Visit II and there was a statistically significant difference between the two mean accident risk scores ( $\mathrm{Z}$ : $3.855, \mathrm{p}<0.001)$. The mean accident risk score for the bathroom was $1.52 \pm 1.47$ (min: 0 , max: 5) at Visit I and $0.38 \pm 0.74$ (min: 0, max: 2) at Visit II and there was a statistically significant difference between the two mean accident risk scores (Z: -3.106, p: 0.002). The mean accident risk score for the living room was $2.57 \pm 1.50$ (min: 0, max: 6) at Visit I and $0.61 \pm 0.49$ (min: 0, max: 1) at Visit II and there was a statistically significant difference between the two mean accident risk scores ( $\mathrm{Z}:-3.757, \mathrm{p}<0.001)$. The mean accident risk score for the bedroom/child room was 1.52 \pm 1.24 (min: 0, $\max : 4$ ) at Visit I and $1.09 \pm 1.94$ (min: 0, max: 3) at Visit II and there was a statistically significant difference between the two mean accident risk scores (Z: -2.714, p: 0.007). The mean accident risk score for the balcony was $0.14 \pm 0.35$ (min: 0, max: 1) at Visit I and 0.04 \pm 0.21 (min: 0, max: 1) at Visit II and there was no statistically significant difference between the two mean accident risk scores (Z: -1.414, p: 0.157).

\section{DISCUSSION}

In this study, over a quarter $(27.6 \%)$ of the children had experienced a home accident within the last six months. Comparing with studies from Turkey; $19.6 \%$ of children in the $0-6$ age group ${ }^{11}, 37.9 \%$ of children within the last year ${ }^{12}, 19.3 \%$ of within the last month, and $16.5 \%$ of within the last year ${ }^{13}$, and $32.8 \%$ within the last year were reported to have a home accident. ${ }^{14}$ Our study revealed a higher frequency of accidence at home.

In the current study, the majority of home accidents $(75 \%)$ were falls. This is confirmed by the literature. ${ }^{15,16}$ Burns and poisoning followed falls in our study. Köse and Bakırcı reported, that $36.4 \%$ of home accidents were due to falls, and $29.5 \%$ due to burns. ${ }^{14}$ Özmen et al. also found that the home accidents most frequently experienced by children in the $0-6$ age group were falls $(48.3 \%)$, which were followed by burns. ${ }^{4}$ Erkal stated $75.4 \%$ of children in the $0-6$ age group, faced falls, burns $(11.8 \%)$ at home. ${ }^{12}$ Further studies, also reported that falls, followed by burns were most frequent in children (17 years). ${ }^{6,14,15}$

The mean accident risk score was 9.04+3.57 (min: 2, max: 16) for all areas of the home. Considering that the highest accident risk score that could be obtained was 40 , the homes included in the study had low risk with respect to home accidents. Unlike the results of the present study, other studies found that mothers were ineffective in implementing safety measures to prevent home accidents. ${ }^{4,6,16}$

We found in our study that the riskiest areas with respect to home accidents were the kitchen and living room. Similarly, Turan and Ceylan found in their study that the living room and kitchen were the rooms where children had accidents most frequently. ${ }^{13}$ In another large-scale, communitybased study conducted by Thein et al. with 2322 children in the $0-15$ age group, most of

Table 3. Houses I and II. Distributions according to Accident Risk Score Average after Home Visit 


\begin{tabular}{|c|c|c|c|c|c|}
\hline $\begin{array}{lll}\text { Home } & \text { Accident } & \text { Components } \\
\text { Hazards } & & \\
\end{array}$ & \multicolumn{2}{|c|}{ 1. Home Visit } & \multicolumn{2}{|c|}{ 2. Home Visit } & Test \\
\hline \multirow[t]{2}{*}{ Kitchen } & \multicolumn{2}{|c|}{$\begin{array}{l}X=3.28 \pm 1.61 \\
(\min : 1-\max : 8)\end{array}$} & \multicolumn{2}{|c|}{$\begin{array}{l}X=1.14 \pm 0.96 \\
(\min : 0-\max : 4)\end{array}$} & \multirow[t]{12}{*}{$\mathrm{p}<0.001$} \\
\hline & $\mathbf{n}$ & $\%$ & $\mathbf{n}$ & $\%$ & \\
\hline Are the pot stems on the oven outward? & 12 & 57.1 & 1 & 4.8 & \\
\hline $\begin{array}{l}\text { Is the cabling of electric appliances in } \\
\text { the place where children can reach? }\end{array}$ & 12 & 57.1 & 1 & 4.8 & \\
\hline Are electrical outlets secure? & 9 & 42.9 & 5 & 23.8 & \\
\hline $\begin{array}{l}\text { Are the buttons of the oven accessible } \\
\text { to children? }\end{array}$ & 6 & 28.6 & 5 & 23.8 & \\
\hline $\begin{array}{l}\text { Are the detergents in the locked } \\
\text { cupboard? }\end{array}$ & 7 & 33.3 & 1 & 4.8 & \\
\hline $\begin{array}{l}\text { Are knives and other sharp tools } \\
\text { securely stored in drawers or cupboard } \\
\text { with safety catches? }\end{array}$ & 8 & 38.1 & 4 & 19.0 & \\
\hline $\begin{array}{l}\text { Do solid foods like nuts, sugar, carrots } \\
\text { and raisins keep away from small } \\
\text { children? }\end{array}$ & 2 & 9.5 & 1 & 4.8 & \\
\hline $\begin{array}{l}\text { Do you have furniture such as chairs, } \\
\text { table and seats at the side of windows? }\end{array}$ & 1 & 4.8 & 1 & 4.8 & \\
\hline $\begin{array}{l}\text { Does the baby feeding chair has a seat } \\
\text { belt? }\end{array}$ & 0 & 0.0 & 0 & 0.0 & \\
\hline $\begin{array}{l}\text { Does the tablecloth has a position that } \\
\text { can be pulled by children? }\end{array}$ & 12 & 57.1 & 5 & 23.8 & \\
\hline \multirow{2}{*}{ P } & \multicolumn{2}{|c|}{$\begin{array}{l}X=1.52 \pm 1.47 \\
\text { (min:0-max:5) }\end{array}$} & \multicolumn{2}{|c|}{$\begin{array}{l}X=0.38 \pm 0.74 \\
(\min : 0-\max : 2)\end{array}$} & \multirow[t]{11}{*}{$P=0.002$} \\
\hline & $\mathbf{n}$ & $\%$ & $\mathbf{n}$ & $\%$ & \\
\hline $\begin{array}{l}\text { Do the children live alone in the } \\
\text { bathroom for even a few second? }\end{array}$ & 2 & 9.5 & 1 & 4.8 & \\
\hline $\begin{array}{l}\text { Does the toilet covers have safety } \\
\text { locks? }\end{array}$ & 3 & 14.3 & 2 & 9.5 & \\
\hline $\begin{array}{l}\text { Is the temperature of the thermostat } \\
\text { high? }\end{array}$ & 0 & 0 & 0 & 0 & \\
\hline $\begin{array}{l}\text { Are electrical household appliances } \\
\text { away from water and children? }\end{array}$ & 6 & 28.6 & 2 & 9.5 & \\
\hline $\begin{array}{l}\text { Do the medicines keep out of children's } \\
\text { reach? }\end{array}$ & 3 & 14.3 & 0 & 0 & \\
\hline $\begin{array}{l}\text { Do cosmetics keep out of children's } \\
\text { reach? }\end{array}$ & 6 & 28.6 & 0 & 0 & \\
\hline $\begin{array}{l}\text { Do razors and scissors keep out of } \\
\text { children's reach? }\end{array}$ & 3 & 14.3 & 0 & 0 & \\
\hline Are floors wet? & 4 & 19.0 & 0 & 0 & \\
\hline Are the toilet cocers closed? & 5 & 23.8 & 3 & 14.3 & \\
\hline \multirow[t]{2}{*}{ Living Room } & \multicolumn{2}{|c|}{$\begin{array}{l}X=2.57 \pm 1.50 \\
(\min : 0-\max : 6)\end{array}$} & \multicolumn{2}{|c|}{$\begin{array}{l}X=0.61 \pm 0.49 \\
(\min : 0-\max : 1)\end{array}$} & \multirow[t]{8}{*}{$\mathrm{p}<0.001$} \\
\hline & $\mathbf{n}$ & $\%$ & $\mathbf{n}$ & $\%$ & \\
\hline $\begin{array}{l}\text { Do children play with toys suitable for } \\
\text { their age? }\end{array}$ & 1 & 4.8 & 0 & 0 & \\
\hline $\begin{array}{l}\text { Are the flowers keep out of reach of } \\
\text { children? }\end{array}$ & 6 & 28.6 & 4 & 19 & \\
\hline $\begin{array}{l}\text { If there is a licensed weapon, is it keep } \\
\text { out of children's reach? }\end{array}$ & 0 & 0 & 0 & 0 & \\
\hline $\begin{array}{l}\text { If there is a stove, is it taken security } \\
\text { measurements around it? }\end{array}$ & 15 & 71.4 & 7 & 33.3 & \\
\hline $\begin{array}{l}\text { Do you have water or food on the stove } \\
\text { that will cause dangerous situations? }\end{array}$ & 12 & 57.1 & 0 & 0 & \\
\hline $\begin{array}{l}\text { Does your child use a baby walker? } \\
\text { Table } 3 \text { continued }\end{array}$ & 3 & 14.3 & 2 & 9.5 & \\
\hline
\end{tabular}




\begin{tabular}{|c|c|c|c|c|c|}
\hline $\begin{array}{l}\text { Do you have furniture such as chairs, } \\
\text { table and seats at the side of windows? }\end{array}$ & 5 & 23.8 & 2 & 9.5 & \\
\hline Are the carpet tips curled up? & 5 & 23.8 & 3 & 14.3 & \\
\hline Do you have any toys to fall into place? & 3 & 14.3 & 1 & 4.8 & \\
\hline $\begin{array}{l}\text { Are the mirrors and glass doors } \\
\text { secured? }\end{array}$ & 4 & 19.0 & 1 & 4.8 & \\
\hline \multirow[t]{2}{*}{ Bedroom/Room of The Child } & \multicolumn{2}{|c|}{$\begin{array}{l}1.52 \pm 1.24 \\
(\min : 0-\max : 4)\end{array}$} & \multicolumn{2}{|c|}{$\begin{array}{l}1.09 \pm 0.94 \\
\text { (min:0-max:3) }\end{array}$} & $p=0.007$ \\
\hline & $\mathbf{n}$ & $\%$ & n & $\%$ & \\
\hline Is your child's bed safe? & 0 & 0 & 0 & 0 & \\
\hline Does the child have toys in his/her bed? & 3 & 14.3 & 1 & 4.8 & \\
\hline $\begin{array}{l}\text { Are there security locks in the } \\
\text { windows? }\end{array}$ & 7 & 33.3 & 7 & 33.3 & \\
\hline $\begin{array}{l}\text { Are heavy and long furnitures fixed on } \\
\text { the wall? }\end{array}$ & 10 & 47.6 & 10 & 47.6 & \\
\hline Do power outlets have safety cover? & 8 & 38.1 & 5 & 23.8 & \\
\hline $\begin{array}{l}\text { Does electric stove leave open while } \\
\text { sleeping. }\end{array}$ & 1 & 4.8 & 0 & 0 & \\
\hline $\begin{array}{l}\text { Does coal stove leave open while } \\
\text { sleeping? }\end{array}$ & 3 & 14.3 & 0 & 0 & \\
\hline \multirow[t]{2}{*}{ Balcony } & \multicolumn{2}{|c|}{$\begin{array}{l}0.14 \pm 0.35 \\
(\min : 0-\max : 1)\end{array}$} & \multicolumn{2}{|c|}{$\begin{array}{l}0.04 \pm 0.21 \\
(\min : 0-\max : 1)\end{array}$} & $\mathrm{p}=0.157$ \\
\hline & $\mathbf{n}$ & $\%$ & $\mathbf{n}$ & $\%$ & \\
\hline $\begin{array}{l}\text { Do high of balcony railings safe } \\
\text { enough? }\end{array}$ & 0 & 0 & 0 & 0 & \\
\hline $\begin{array}{l}\text { The ranges of balcony railings safe } \\
\text { enough? }\end{array}$ & 1 & 4.8 & 1 & 4.8 & \\
\hline $\begin{array}{l}\text { Do you have a chair or table on the } \\
\text { balcony that children can climb on? }\end{array}$ & 1 & 4.8 & 0 & 0 & \\
\hline Is floor of balcony wet? & 1 & 4.8 & 0 & 0 & \\
\hline Total & $\begin{array}{l}9.0 \\
(\mathrm{mi}\end{array}$ & $\mathrm{x}: 16)$ & $\begin{array}{l}3.2 \\
(\mathrm{mi}\end{array}$ & $\begin{array}{l}.02 \\
\max : 8)\end{array}$ & $\mathrm{p}<0.001$ \\
\hline
\end{tabular}

the home accidents that occurred within the last year were mostly in the living room and then in the kitchen. ${ }^{17}$ Since there are many factors that may lead to accidents in the kitchen, we believe that it is extremely important that the child is kept away from the kitchen as much as possible and that the factors that may result in accidents are removed from this area. The living room, which is a resting place for parents, is at the same time a play and leisure area for children. As this area is used for various activities, it becomes an important accident area for children. ${ }^{14}$ Considering that children spend a large portion of their times in the living room, it is also necessary to identify the risk factors involved in this area and to take measures against them in order to reduce home accident based injuries.

Age and educational status of the mother, income status of the family, number of people living at home, or accident history of the child in the last six months showed no impact on the accident risk score at the first visit ( $p>0.05)$. Similar to our study, Köse and Bakırc1 found in their study, that educational status of mothers did not affect the frequency of child accidents, but the frequency of home accidents was lower in children living in a nuclear family than in those living in an extended family. ${ }^{14}$ Erkal reported that educational status and maternal age, family type, income status, and children's history of home accidents played a role in the level of safety provided by mothers, who had children in the 0-6 age group, decreasing the prevention of home accidents. ${ }^{12}$

The accident risk scores of families having a single child were significantly higher than those having three children $(\mathrm{p}<0.05)$. Similar to our study results, Özmen et al. found, that having three or more children in a family increased the mother's score for safety measures to prevent home accidents. ${ }^{4}$ It was stated that this result was due to maternal experience. Unlike the results of our study, Balibey et al. found, that when there were more than two children in a family, the mean home insecurity score increased. ${ }^{15}$ A different result was found in a study, where having a single child in the 0-6 age group increased the safety level for preventing home accidents. ${ }^{12}$ 
It was emphasized in the literature that parents and particularly mothers, should be given education on the measures to prevent home accidents at any opportunity. ${ }^{4,12,18}$ It was suggested that such training would be effective in reducing home accident risks and establishing a safe household environment. ${ }^{4,13}$

In the present study, risks that were identified in apartments, using the Home Safety Checklist before the training intervention, revealed a statistically significant decrease after the training provided to mothers ( $\mathrm{p}<0.01$ ). Studies in the literature confirm our result. Similarly, King et al. conducted home visits and provided training for the purpose of preventing home accidents in childhood. ${ }^{19}$ They found changes in attitudes and practices in the majority of families $(63 \%)$ after the visits. In the study of Altundağ and Öztürk, safety measures increased at home and the prevalence of accidents decreased after the training given to the mothers of $0-6$ year old children regarding home accidents. ${ }^{18}$ Posner et al. gave training to the parents of children, who presented to the emergency service for some reason and found that, after training, home safety scores increased and the frequency of accidents decreased. ${ }^{20}$ King et al. observed that the training provided to mothers through home visits, in order to reduce the frequency of accidents in children and to improve safety measures in the home environment, resulted in increased knowledge, confidence, and accident-preventing measures. ${ }^{19}$ Clamp and Kendrick found in their study, which aimed at establishing a safe home environment for families with children less than five years of age, that the mothers, who received training took safety measures against accidents in the home environment. $^{21}$

\section{Study limitations}

Although population of the study consisted of 350 families, we reached only 21 families, because the acceptation rate was low. Thus, the results of the study are not generalizable to the whole population. The study has some other limitations, such as some problems for the families to allocate time for home visit, because of having little child at home and ignoring education on home accidents.

\section{CONCLUSIONS}

In conclusion, education given to families with children in the 0-6 age group about home accidents was effective in decreasing accident risk at home. In light of these study results, we suggest that families having children in the $0-6$ age group should be provided information on home accidents, their awareness about the issue should be increased, and nurses should assess the home environment through home visits to identify factors that may lead to accidents, ensuring that measures are taken and raising awareness in families by health education.

Funding: In order to conduct this research, financial support was received from the Scientific Research Projects Division of Ege University (Project No: 2011/OSYO/001). The financing organization had no impact on study design, conduct or reporting of results.

\section{REFERENCES}

1. Alptekin F. Aksaray il merkezinde ev kazaları epidemiyolojisi korumaya yönelik tutum ve davranışlar ev kazalarına yönelik ilkyardım bilgi düzeyi. TC. Süleyman Demirel Üniversitesi Sağlık Bilimleri Enstitüsü Halk Sağlığı Anabilim Dalı Yüksek Lisans Tezi, Isparta 2004;45-48.

2. Çalışkan K, Avcı Ö, Acar V, Dönmez YC. Examination of mothers' first aid practices regarding with falls their 0-6-year-old children. Maltepe Üniversitesi Hemşirelik Bilim ve Sanatı Dergisi 2010;3(3):2-9.

3. Turan T, Dündar AS, Yorgancı M, Yıldırım Z. The prevention of home accidents among children aged 0-6 years. Turkish Journal of Trauma \& Emergency Surgery 2010;16(6):552557.

4. Özmen D, Ergin D, Şen N, Çetinkaya AÇ. To identify safety measures of mothers of children aged between 0 and 6 years against home accidents. Aile ve Toplum 2007; Nisan-MayısHaziran:13-19.

5. Asildizer M, Yavuz MS, Albek E, Gurol C. Infant and adolescent deaths due to home accidents in Istanbul. Turkish Journal of Pediatrics 2005;47(2):141-149.

6. Yılmaz Kurt F, Aytekin A. 0-6 yaş grubu çocuklarda ev kazaları. HSP 2015;2(1):22-32.

7. Şahin YY. Çocuklarda görülen ev kazalarında ailelerin yaptığı uygulamalar ve alınan güvenlik önlemleri. T.C. Mersin Üniversitesi Sağlık Bilimleri Enstitüsü Hemşirelik Anabilim Dalı Yüksek Lisans Tezi, Mersin 2012:18-23.

8. Home safety checklist for parents of children 04 years of age. Kidsafe Child Accident Prevention Foundation of Australia. 2010 Retrieved from www.kidsafesa.com.au (accessed 16.02.2017)

9. Home safety checklist are children safe in your home? North Dakota Department of Health. 2011 Retrieved from http://www.ndhealth.gov/injury/publications/h ome_safety.pdf (accessed 16.02.2017).

10. Kohl's injury prevention program home safety checklist. The Children's Hospital of 
Philadelphia. www.chop.edu. (accessed 16.02.2017).

11. Karatepe TU, Akış N. 0-6 yaş çocuklarda ev kazası geçirme sıklığı ve ilişkili faktörler. Uludağ Üniversitesi Tıp Fakültesi Dergisi 2013;39(3):165-168.

12. Erkal S. Identification of the number of home accidents per year involving children in the 0-6 age group and the measures taken by mothers to prevent home accidents. The Turkish Journal of Pediatrics 2010; 52:150-157.

13. Turan T, Ceylan SS. 0-6 yaş grubu çocukları olan annelerin ev kazalarını önlemek için aldıkları güvenlik önlemlerinin aile özelliklerine ve ev kazaları sıklığına gore değerlendirilmesi. Sağlık ve Toplum Dergisi 2007;17(4):52-58.

14. Köse OÖ, Bakırcı N. Çocuklarda ev kazaları. STED 2007;16(3):31-35.

15. Balibey M, Polat S, Ertem İ, Beyazova U, Şahin F. Factors causing home accidents in childhood. STED 2011;20(3):89-97.

16. Öztürk C, Sarı YH, Bektaş M, Elçigil A. Home accidents and mothers measurements in preschool children. Anatol J Investig 2010;4(1):15-21.

17. Thein MM, Lee BW, Bun PY. Childhood injuries in Singapore: a community nationwide study. Singapore Med J 2005; 46(3):116-121.

18. Altundağ S, Öztürk MC. The effects of home safety education on taking precautions and reducing the frequency of home accidents. Turkish Journal of Trauma \& Emergency Surgery 2007;13(3):180-185.

19. King WJ, LeBlanc JC, Barrowman NJ, Klassen $\mathrm{TP}$, Bernard-Bonnin AC, Robitaille Y, et al. Long term effects of a home visit to prevent childhood injury: three year follow up of a randomized trial. Injury Prevention 2005; 11:106-109.
20. Posner JC, Hawkins LA, Espana FG, Durbin R. A randomized, clinical trial of a home safety intervention based in an emergency department setting. Pediatrics 2004; 113:1603-1608.

21. Clamp M, Kendrick D. A randomised controlled trial of general practitioner safety advice for families with children under 5 years. BMJ 1998;316(7144):1576-1579. 